\title{
Lectio praecursoria, Tieto liikkuu, potilas ei - neurologisen lähetepotilaan etähoitomallin käyttöönotto ja arviointi
}

\author{
Hanna Kuusisto, 23.11.2016
}

\section{Arvoisa kustos, arvoisa vastaväittäjä, arvoisat kuulijat,}

Erikoissairaanhoidon palvelujen kysyntä ja kustannukset ovat Suomessa olleet jatkuvassa kasvussa. Pääasiallisina syinä on nähty ikääntyneiden määrän kasvu, terveydenhuollon menetelmien kehittyminen sekä väestön lisääntynyt tietoisuus. Terveydenhuollon vuosikustannukset ovat 19.5 miljardia euroa, joka on $9.5 \%$ Suomen bruttokansantuotteesta. Terveydenhuolto vie kuntien budjetista neljänneksen. Erikoissairaanhoidon kustannukset ovat lisääntyneet perusterveydenhuollon kustannuksia nopeammin. Viime vuosina kasvunopeus on ollut $0.6 \%$. Terveydenhuollon rahoitus on vielä toistaiseksi monikanavainen. Kunnat vastaavat $40 \%$ kustannuksista, valtio $20 \%$, KELA $14 \%$ ja lopuista vastaa yksityiset tahot $\mathrm{mm}$. kansalaiset ja vakuutusyhtiöt.

Suomen julkinen terveydenhuoltojärjestelmä muodostuu terveydenhuoltolain, kansanterveyslain ja erikoissairaanhoitolain säätelemästä perusterveydenhuollosta ja erikoissairaanhoidosta. Henkilön ottaminen erikoissairaanhoitoon kiireetöntä hoitoa varten edellyttää lääkärin tai hammaslääkärin tutkimukseen perustuvaa lähetettä, joka on perinteisesti johtanut vastaanottokäyntiin jonottamisen jälkeen. Kansalainen voi vapaasti valita mihin terveyskeskukseen hän haluaa hakeutua hoitoon ja yhdessä perusterveydenhuollon lääkärin kanssa myös sen, mihin erikoissairaanhoidon yksikköön haluaa tulla lähetetyksi. Oleellista oikea-aikaisessa ja sujuvassa potilaan liikkumisessa on laadukas tiedonkul- ku perusterveydenhuollon ja erikoissairaanhoidon välillä. Tieto liikkuu lähetteen välityksellä.

Vaikka terveyskeskuslääkärit lähettävätkin vain alle 10 $\%$ potilaistaan erikoissairaanhoitoon, johtaa se merkittävään terveydenhuollon kustannukseen. Erikoissairaanhoidon potilaista $70 \%$ on otettu hoitoon nimenomaan terveyskeskuslääkärin lähetteen perusteella. Joka kymmenes potilas erikoissairaanhoidossa on otettu hoitoon sairaalan sisäisten konsultaatioiden perusteella ja loput potilaat tulevat yksityissektorilta. Lisäkustannuksia aiheuttaa heikko hoidon saatavuus. Jonottaminen on tehotonta, kallista ja priorisointikeinona epäeettinen. Terveyspalveluiden saatavuus kertoo hoitojärjestelmän toimivuudesta. Pitkä jono voi olla merkki voimavarojen puutteesta, niiden käytön ongelmista tai toiminnan organisoinnin heikkoudesta. Jonon pituudella on perinteisesti perusteltu lisäresurssien tarvetta. Tutkimuksissa ei kuitenkaan ole voitu osoittaa jonon pituuden ja käytettävissä olevien voimavarojen välillä olevan yhteyttä, sillä tarjonnan kasvaessa lisääntyy myös kysyntä.

Jonottamisen ongelmaa on yritetty ratkaista ns. hoitotakuulailla: Terveydenhuoltolaissa säädetään kiireettömän hoitoon pääsyn enimmäisaikarajat. Kuuden kuukauden hoitotakuu astui voimaan 1.3.2005 ja sen määräaikaa tiukennettiin kolmeen kuukauteen 1.5.2011 (kuva). 


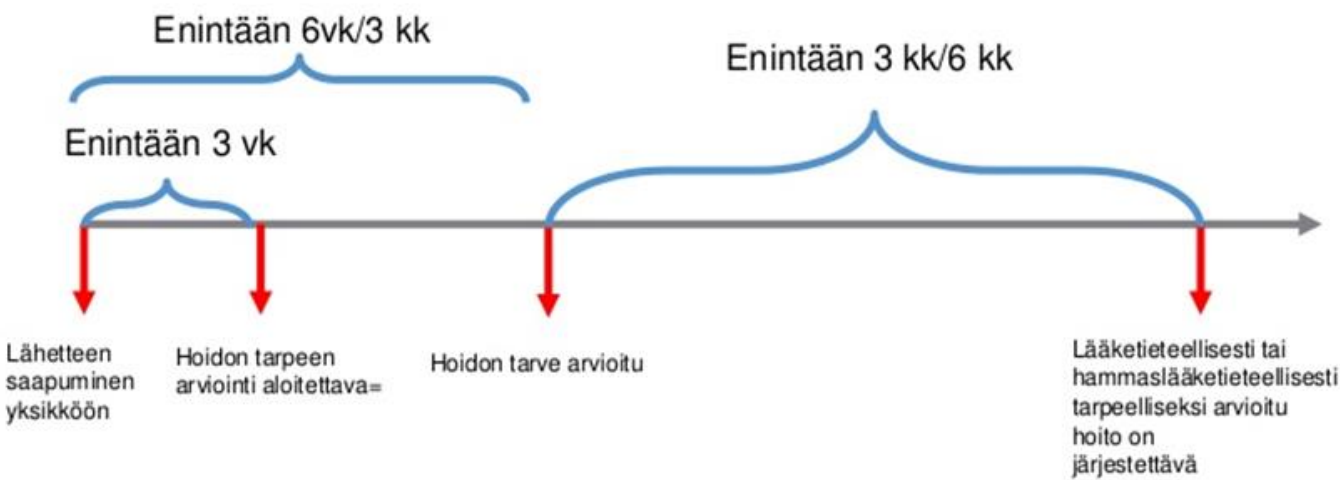

Hoitotakuun myötä, ja jopa sitä ennakoivasti, on perusterveydenhuollossa otettu käyttöön erilaisia uusia toimintamalleja hoidon saatavuuden tehostamiseksi, $\mathrm{mm}$. sairaanhoitajien vastaanottotoiminta ja terveydenhuolIon ammattihenkilöiden antama puhelinneuvonta, minkä on todettu merkittävästi vähentävän lääkärin vastaanottokäyntien tarvetta. Erikoissairaanhoidossa vastaavaa toimintaa on kokeiltu vähän, vaikka tiedetään, että kolmannes sairaalaan saapuvista lähetteistä on lääketieteellisesti arvioituna aiheettomia eikä siis osa erikoissairaanhoitoon lähetetyistä potilaista tarvitsisi varsinaista vastaanottokäyntiä lainkaan. "Odottavan aika on pitkä", ja pitkän jonotusajan tiedetäänkin olevan pääsyy vastaanotolle saapumatta jättämiseen erikoissairaanhoidossa ja keskeisin potilaiden tyytymättömyyden aihe. Potilaat toivovat ensisijaisesti tietoa oireistaan ja niiden hoitomahdollisuuksista, eivätkä välttämättä vastaanottotaikaa.

Hoitotakuu ei yksin ole kyennyt ratkaisemaan jonottamisen ongelmaa. Avuksi on tullut Tieto- ja viestintäteknologian käyttö terveydenhuollossa, eli sähköiset terveyspalvelut. Sähköisiä terveyspalveluita on kehitetty 80luvulta lähtien ja ne ovatkin muuttaneet merkittävästi terveydenhuollossa tapahtuvaa tiedonkulkua. Sähköiset terveyspalvelut ovat keskeisessä asemassa uudessa Sosiaali- ja terveysministeriön Sote-tieto hyötykäyttöön 2020 strategiassa, jossa tavoitteena on tasapuolinen, vaikuttava ja asiakaslähtöinen sosiaali- ja terveyspalveluiden saatavuus. Etälääketiede on osa sähköisiä terveyspalveluita, ja etähoito on osa etälääketiedettä. Etähoito on tapahtuma, jossa potilas on keskeisessä asemassa ja mukana päätöksenteossa, mikä erottaa sen konsultaatiosta, jossa vain asiantuntijat vaihtavat tie- toa. Yksinkertaisimmillaan etähoitoon riittää helppo ja halpa puhelin. Etähoito on asiakaslähtöistä lähipalvelua, eli hoito tuodaan kotiin vaivatta ja vähin kustannuksin.

Sähköinen lähete ja palautejärjestelmä mahdollistavat nopean tiedon siirron erikoissairaanhoidon ja perusterveydenhuollon välillä. Sähköiseen lähetteeseen voidaan suhtautua konsultaationa toimeksiannon sijaan, mikä yhdessä sähköisen potilaskertomuksen kanssa mahdollistaa potilaan nopean hoidontarpeen arvioinnin ja jopa hoidon erilaisia etähoidon menetelmiä esim. puhelinta käyttämällä. On siis mahdollista kytkeä erikoislääkäri potilaan hoitoon perusterveydenhuollossa siirtämällä potilaiden sijasta tietoa.

Sosiaali- ja terveydenhuollon tiedonhallinnan alaan kuuluvassa väitöstutkimuksessani "Tieto liikkuu, potilas ei" kuvataan neurologisen lähetepotilaan etähoitomallin käyttöönotto ja monitahoarviointi. Se sisältää osatöinä julkaistut rekisteritutkimukset etähoidon merkityksestä neurologisen hoidon saatavuuteen ja turvallisuuteen, sekä kyselytutkimukset potilaiden ja perusterveydenhuollon lääkäreiden etähoitokokemuksista ja asenteista.

Väitöskirjatutkimuksessani osoitettiin, että valikoitujen neurologisten lähetepotilaiden etähoito puhelimitse paransi merkittävästi kaikkien potilaiden hoidon saatavuutta. Suurin osa etähoidetuista lähetepotilaista oli tyytyväisiä etähoitoon välittömästi puhelinkontaktin jälkeen ja vielä 8-10 kuukautta myöhemmin. Myös perusterveydenhuollon lääkärit olivat tyytyväisiä neurologisen lähetepotilaansa etähoitoon, mutta suhtautuivat varauksellisesti potilasturvallisuuteen. Vuosina 2008-2014 ei Kanta-Hämeen keskussairaalan neurolo- 
gian yksikköön ollut kuitenkaan kirjattu etähoitoon liittyviä muistutuksia, kanteluita tai potilasvahinkoilmoituksia. Sen sijaan huono hoidon saatavuus on aiemmin ollut yleinen potilaiden ilmoittamien haittatapahtumien syy.

Hanna Kuusisto 2016. Tieto liikkuu, potilas ei - neurologisen lähetepotilaan etähoitomallin käyttöönotto ja arviointi. Publications of the University of Eastern Finland. Dissertations in Social Sciences and Business Studies,135. Kuopio: Itä-Suomen yliopisto; 2016.

http://urn.fi/URN:ISBN:978-952-61-2283-0
Väitöskirjatutkimukseni perusteella neurologisen lähetepotilaan etähoito on toimiva erikoissairaanhoidon lähipalvelumuoto, joka parantaa hoidon saatavuutta ilman lisäresursseja. 